\title{
"ESCRITAS AUTOBIOGRÁFICAS" E O CINEMA DE PEDRO ALMODÓVAR
}

\section{AUTOBIOGRAPHICAL WRITINGS AND THE CINEMA MADE BY PEDRO ALMODOVAR}

\author{
Ramon Victor Belmonte Fontes ${ }^{1}$
}

\section{RESUMO}

Pensar como os mecanismos de violência e, mais especificamente, o abuso sexual, participam da construção subjetiva das crianças é um dos objetivos deste artigo. Para fazer isso, discuto como a experiência de abuso sexual na infância participou da construção das minhas próprias subjetividades. As reflexões, aqui propostas, não buscam uma história totalizante, nem um tipo de generalização sobre as experiências dos abusos sexuais na infância. Ao invés disso, elas seguem por caminhos pessoais (inseridos, também, em processos sociais) e pretendem apresentar um olhar localizado no tempo e espaço que sirvam para trazer à tona mais fragmentos discursivos e reflexivos a respeito de tal violência. Para isso, será dada ênfase nas minhas narrativas, entendidas aqui como autobiográficas, e nos filmes "Fale com ela" (2002), "Má Educação" (2003) e "Volver" (2005), do cineasta Pedro Almodóvar, como instrumentos que discutem, mobilizam e ressignificam os caminhos subjetivos possibilitados a cada um de nós. A proposta metodológica desta pesquisa segue por caminhos que não coadunam com uma escrita acadêmica clássica. Escrever, no âmbito deste trabalho, significa minar os discursos pré-moldados sobre as experiências memorialísticas, bem como apresentar novos olhares e subjetividades que não reproduzam um entendimento reducionista e inexorável das complexas situações de abuso sexual na infância. Em resumo, é uma escrita de pretensões políticas que coloca em devir a violência experimentada na idade infantil e tem o intuito de não reduzir os indivíduos violentados aos estereótipos de futuro algoz e/ou mártir eterno.

Palavras-chave: Sexualidades. Infâncias. Abuso Sexual. Autobiografia. Cartografia. Pedro Almodóvar.

${ }^{1}$ Mestre pelo Programa Multidisciplinar de Pós-graduação em Cultura e Sociedade, da Universidade Federal da Bahia. E-mail: ramon_fontes@hotmail.com.br. 


\begin{abstract}
One of the purposes of this article is to think how the mechanisms of violence and, more specifically, sexual abuse, participate in the subjective construction of children. To do this, I discuss how the experience of childhood sexual abuse participated in the construction of my own subjectivities. The reflections proposed here don't seek a totalizing history or a kind of generalization about experiences of sexual abuse in childhood. Instead, they go for personal paths (inserted also in social processes) and intend to present a located look in time and space that will serve to bring out more discursive and reflective pieces about such violence. For this, emphasis will be placed on my narratives, understood here as autobiographical, and on the filmes Talk to her (2002), Bad Education (2003) and Volver (2005) made by the filmmaker Pedro Almodóvar, as tools to discuss, mobilize and resignify the subjective ways enabled each of us. The methodological proposal of this research will in ways that don't sit well with a classic academic writing. Writing in this paper means undermining the precast speeches on memorialistic experiences and present new perspectives and subjectivities that don't replicate reductionist and inexorable understanding of complex situations of sexual abuse. In short, it's a politic writing that puts in devir the violence experienced in childhood age and is intended not to reduce individuals violated in the stereotypes of future tormentor and/or eternal martyr.
\end{abstract}

Keywords: Sexualities. Childhoods. Sexual Abuse. Autobiography. Cartography. Pedro Almodóvar. 


\section{Introdução}

Essas linhas são o resultado possível de uma pesquisa ${ }^{2}$ que não se esgota, que continua a ser escrita em variados contextos. A partir dos filmes "Fale com ela", "Má educação" e "Volver", todos do cineasta Pedro Almodóvar ${ }^{3}$, - que trabalham a temática do abuso sexual ${ }^{4}$ - eu busco propor novos sentidos à essa experiência de violência (sempre partindo de fragmentos da minha infância). Em outras palavras, ao utilizar os argumentos cinematográficos das histórias de Almodóvar, construo uma ponte para que xs leitorxs ${ }^{5}$ topem o desafio de pensar o abuso sexual na infância, levando em consideração as críticas aos discursos e instituições da heteronorma [via reflexões de Judith Butler (2015; 2010)]. É a partir desses retalhos que costuro, aqui, uma reflexão entre: a tutela do corpo e da subjetividade infantil pelo indivíduo adulto, as normas de sexualidade e gênero que incidem sobre tais corporalidades e, por último, ao ato de escrever como uma [re]ação contra o abuso sexual.

Esse artigo tem a intenção de reafirmar a importância em se falar sobre violência e infância, de forma que a potência política advinda deste ato contribua para diminuir, em alguma medida, o sofrimento subjetivo que acompanha os indivíduos subjugados pelas experiências de violência e que são silenciados pelas normas discursivas que os leem como desviantes, anormais. De forma sintética, apresento e reafirmo a

\footnotetext{
${ }^{2}$ Este texto consiste em um recorte da dissertação "Infância, violências e sexualidade: uma aventura autobiográfica com Pedro Almodóvar", orientada pelo professor doutor Leandro Colling e defendida em 2016 no Programa Multidisciplinar de Pós-graduação em Cultura e Sociedade, da Universidade Federal da Bahia.

3 Pedro Almodóvar Caballero, nascido na década de 1950, é um dos cineastas espanhóis mais aclamados da atualidade. Sua obra contém posicionamentos que abarcam: a crítica social, a reivindicação de territórios, a relação do ser humano com o corpo e o desejo; A instituição social da família tem, também, importante papel na sua obra.

${ }^{4}$ Neste artigo utilizo o termo abuso sexual para designar "qualquer ato de natureza sexual cometido contra crianças ou adolescentes, imposto pela força física, pela ameaça ou por outras formas de coerção". Essa noção é difundida pela Secretaria Especial de Direitos Humanos, ligada ao Ministério da Justiça e Cidadania do Governo Federal do Brasil. Disponível em: < http://goo.gl/hfVsQO>. Acesso em 22 ago. 2016. ${ }^{5}$ Ao longo deste artigo, ao grafar as palavras com "x", mantenho diálogo com os contemporâneos Estudos Queer e busco não generificar os vocábulos. Nesse sentido, apesar da herança machista e misógina sobre a qual a língua portuguesa foi construída ao longo dos tempos, tento minimizar os seus efeitos e produzir uma escrita que leve em consideração, em suas entrelinhas, a participação dos mais variados corpos, subjetividades e indivíduos.
} 
potência política do ato de escrever como uma [re]ação contra o abuso sexual.

Discutir sobre a violência sexual na infância é o desafio maior que esses escritos cumprem, pois mobiliza uma série de pré-conceitos, equívocos e técnicas de educar, cometidos pelas instituições sociais, em prol da construção de uma nova abordagem e um novo entendimento sobre a relação existente entre desejos, infâncias, sexualidades, violências, educação e subjetividades. Ao mergulhar na atmosfera almodovariana e no trabalho produzido pela memória do próprio pesquisador, cinema, afeto, memórias e escrita poética tornam-se ferramentas potentes para desconstruir, desestabilizar e interseccionalizar os discursos de violência que permanecem hegemônicos.

\section{Fragmentos almodovarianos: usos e abusos}

[Cenas almodovarianas 1] - Há trinta e oito anos, em 20 de maio de 1978, na cidade de Wuppertal, Alemanha, a coreógrafa e bailarina alemã Pina Bausch estreava a sua famosa obra "Café Müller"6. Em um cenário cinzento, repleto de mesas e cadeiras em madeira maciça que são derrubadas e levantadas o tempo inteiro ao longo do cenário, entrecortado por diferentes tipos de portas - as quais permitem um entrae-sai contínuo de inúmeros corpos -, Pina nos transporta para o interior de um bar melancólico e silenciosamente sombrio. Nele podemos acompanhar os frenéticos encontros e desencontros de indivíduos que bailam de olhos cerrados, vestidos com trajes socialmente requintados, algumas peças de dormir, ou ainda, com seios desnudos. Nosso olhar ora segue os passos curtos e rápidos que ecoam do salto de uma das bailarinas, ora bailam com os corpos de um casal que se chocam mutuamente contra as paredes do local (Fig.1).

Num diálogo intertextual, nós espectadores somos transportados para os minutos iniciais do filme "Fale com ela" (2002), escrito e dirigido por Pedro Almodóvar. À medida que uma cortina de teatro se abre na tela, somos levados pelo cineasta espanhol ao mesmo "Café" criado por Pina

\footnotetext{
${ }^{6}$ A obra foi criada em 1978 e ganhou uma versão para a televisão em 1985 a qual pode ser conferida integralmente no site < https://vimeo.com/118644761> . Acesso em 18 abr. 2016.
} 
em sua obra. No desenrolar da cena, somos, simultânea e metalinguisticamente, deglutidxs: pelo teatro [onde se passa/passou a coreografia], pelo cinema [que retrata a coreografia, seus espaços e a narrativa almodovariana que se inicia] e pela dança [que remonta aos movimentos e intenções de estreia da obra de Pina Bausch], ao mesmo tempo em que começamos a supor quais os caminhos narrativos serão privilegiados pelo cineasta para contar a sua história.

Figura 1 - Cenas de Café Müller extraídas da película Fale com ela (2002)

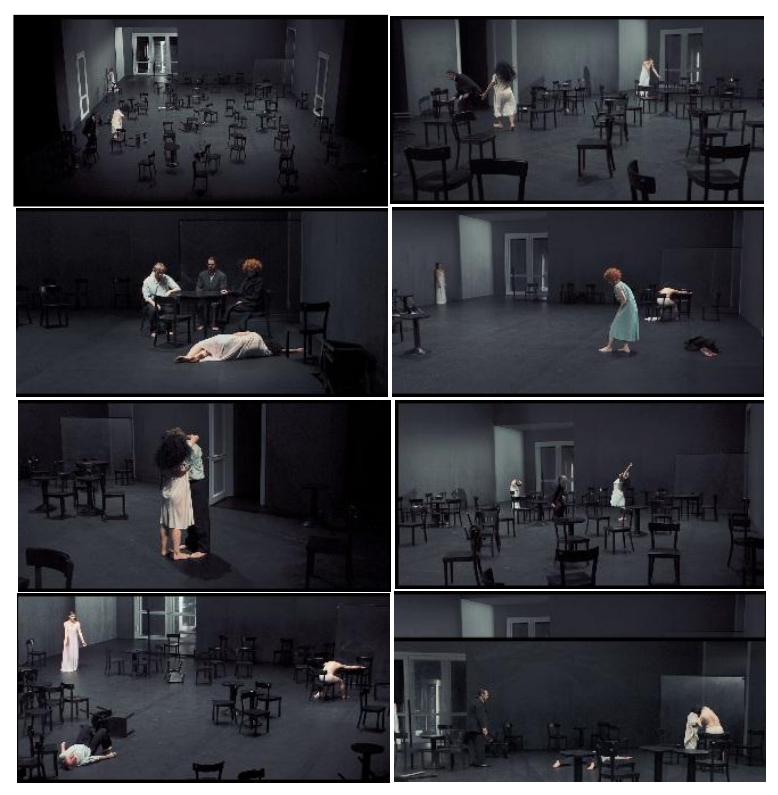

Nas linhas desse artigo, quando eu "falo com ela/ele" ou, ainda, quando "falo dela/dele" refiro-me multiplamente à narrativa de abuso sexual experienciada na infância, por esse autor que vos escreve, e aos fragmentos fílmicos dos filmes de Pedro Almodóvar. É a partir desses retalhos que costuro, aqui, uma reflexão entre: a tutela do corpo e da subjetividade infantil pelo indivíduo adulto, as normas de sexualidade e gênero que incidem sobre tais corporalidades e, por último, ao ato de escrever como uma [re]ação contra o abuso sexual. 
A película "Fale com ela" narra a história de quatro indivíduos que se encontram nas dependências do hospital particular "El Bosque": Benigno, jovem enfermeiro e trabalhador da clínica; Marco, escritor de uma emotividade latente; Lydia, toureira profissional que sofre um acidente em uma de suas corridas e, por último, Alicia, uma jovem bailarina amante dos filmes e da literatura. Para os propósitos desse artigo vou me ater, inicialmente, à relação entre Alicia e Benigno, pois é a partir desse contato que Almodóvar relata aos espectadores uma experiência de abuso sexual, experiência essa a que me proponho refletir aqui. Hablemos!

Após sofrer um acidente de carro numa noite chuvosa, a bailarina Alicia entra em estado de coma e é internada na clínica onde o enfermeiro Benigno trabalha como cuidador. Nos minutos inicias da película, o rapaz, em companhia de outra enfermeira, lava, com extrema dedicação, o corpo da jovem recém-chegada. É uma cena considerada comum em ambientes hospitalares, nos quais os agentes de saúde cuidam dos corpos enfermos e/ou inertes. Porém, na cena em questão, o diretor espanhol sugere uma relação de cuidado muito mais afetuosa e eroticamente desejante (Fig 2).

Figura 2 - Benigno cuida de Alicia - cena do filme Fale com ela (2002)

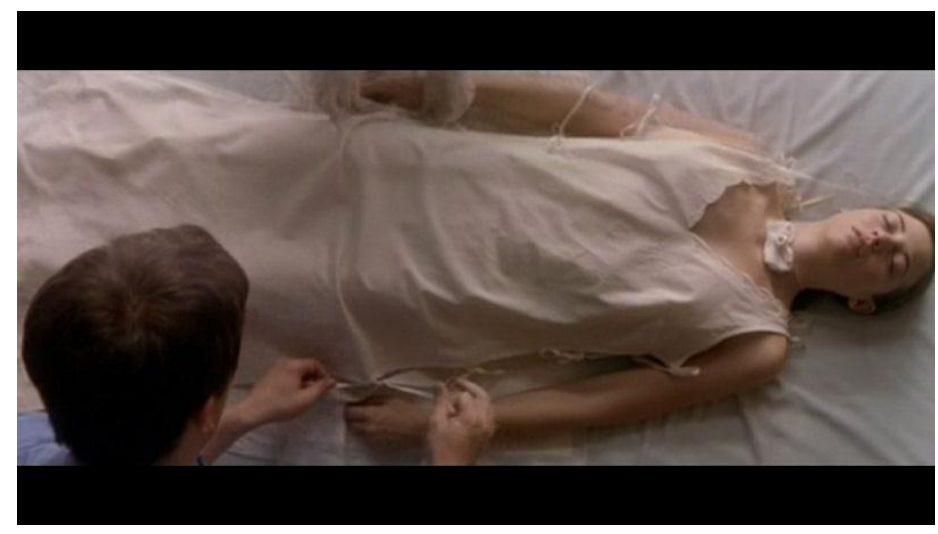

Apesar do corpo imóvel da paciente, Benigno a trata como se tal inércia não existisse - pelo menos no plano subjetivo -, ele conversa sobre cenas do cotidiano, questiona-a sobre preferências estéticas (cortes de 
cabelo, roupas e decoração do quarto), pergunta e "ouve" as respostas expressadas através da imobilidade de Alicia, reproduz fielmente, através da contação de histórias, os filmes e peças a que assiste cotidianamente enquanto Alicia mantém-se inerte. Em um desses relatos artísticos Benigno detalha para a letárgica mulher a coreografia "Café Muller" e de como, ao final da apresentação, conseguiu o autógrafo da própria Pina Bausch, numa fotografia do espetáculo, onde se lia: "Espero que vença os obstáculos e comece a dançar!".

A frase esperançosa de Pina nos traz agora às linhas dessa minha escrita, isto é, a partir dela me ponho a refletir sobre as circunstâncias do meu abuso, na infância, e de como o silêncio que mantive, ao longo dos anos sobre tal experiência, se aproxima poeticamente do estado de coma que assistimos na personagem Alicia. Se nela o obstáculo é a incapacidade de falar e de se expressar emocionalmente por causa do estado físico e do coma, derivado do acidente, no caso do infante que fui[fomos] o obstáculo se resumia, igualmente, nessa impossibilidade de falar sobre a violência que sofria cotidianamente, incapacidade essa derivada do medo de sofrer sanções de todos os tipos, portanto, uma incapacidade subjetivada.

A punição poderia vir de qualquer lugar, mas a instituição social que mais me amedrontava era a família. Ainda criança compreendi que a minha família, nascida e cultivada num ambiente militarmente áspero, com limites muito rígidos de hierarquia e papéis de gênero, certamente assumiria o papel inquisidor, no momento mesmo em que eu expressasse como o meu vizinho "brincava de pinto"7 comigo. Isto é, era como confessar que as fronteiras de gênero tidas como corretas e reiteradas diariamente por todxs elxs (mãe, pai, tios, tias, primo, prima, avô, avó...) estavam sendo rasuradas cotidianamente sob seus desatentos olhares. Jamais aceitariam tal afronta!

Hoje, ao refletir sobre esse medo, ecoam em mim os escritos de Preciado (2014) quando questiona “Quem defende a criança queer?”. Para x autorx, motivadx pelas manifestações conservadoras "em defesa da criança e da infância", ocorridas na França em 2013, essa criança reivindicada por tais discursos - entre eles o discurso da família nuclear

7 "Brincar de pinto" era como o vizinho metaforicamente me "convidava" para as sessões de abuso sexual. 
burguesa ocidental, a qual elxs pretendem proteger - simplesmente "não existe". Elx continua:

Os defensores da infância e da família apelam para a figura política de uma criança que eles constroem, uma criança pressupostamente heterossexual e com o gênero normatizado. Uma criança que privamos de qualquer força de resistência, de qualquer possibilidade de fazer um uso livre e coletivo de seu corpo, de seus órgãos e de seus fluidos sexuais. Essa infância que eles pretendem proteger exige o terror, a opressão e a morte. [...] aproveitam-se do fato de que é impossível para uma criança rebelar-se politicamente contra o discurso dos adultos: ela é sempre um corpo a quem não se reconhece o direito de governar (PRECIADO, 2014, s/p).

O medo das sanções, principalmente as familiares, que me acompanhou durante toda a infância e boa parte da adolescência, serviram como justificativa para o silêncio que mantive sobre o abuso sexual sofrido. $\mathrm{O}$ silêncio social, produzido e reproduzido pelos indivíduos, é violento em muitos sentidos: ele reafirma o discurso heteronormativo familiar, na medida em que não desestabiliza - justamente por não denunciar -aquela narrativa coerente entre sexo, gênero, desejo e prática sexual (BUTLER, 2010) [nesse caso, uma prática violenta sobre um corpo lido como indefeso, tutelado], assim a minha subjetividade continuava refém daquela prática e de suas possíveis sanções; era violento, pois se mantinha oculto em todos os espaços, impedindo, portanto, o debate, a reflexão e uma ação de repúdio naquela construção familiar; era violento, pois produzia um duplo movimento na criança que fui, isto é, me enquadrava numa mudez etária, justamente por pertencer à condição de criança tutelada pelos olhares e vozes dxs adultxs e, ao mesmo tempo, impedia-me de romper essa tutela, pois as ameaças sugeridas cotidianamente paralisavam-me ante à possibilidade real de ser castigado ou até mesmo morrer.

Ao voltarmos novamente para o texto de Preciado (2014) e reler a minha história familiar tendo a concordar com o argumento de que "a criança e a infância, como motivo de proteção da instituição familiar" é uma farsa. Ou seja, o destino de tal proteção não são as corporalidades e subjetividades infantis, em toda sua potência, mas sim a proteção e manutenção da norma heterossexual. A produção discursiva em torno da infância é muito mais reafirmação da norma do que a multiplicação 
de possibilidades subjetivas e/ou identitárias. Preciado (2014), inspiradx por Michel Foucault, sintetiza:

A criança-a-ser-protegida [...] é o efeito de um dispositivo pedagógico perigoso, o lugar de projeção de todas as fantasias, o álibi que permite ao adulto naturalizar a norma. A biopolítica [segundo Michel Foucault, um poder que se exerce sobre os corpos e as populações] é vivípara e pedófila. A reprodução nacional depende dela. A criança é um artefato biopolítico que garante a normalização do adulto. A polícia do gênero vigia o berço dos seres vivos que estão por nascer, para transformá-los em crianças heterossexuais. A norma faz sua ronda em torno dos corpos frágeis. Se você não for heterossexual, a morte o espera. A polícia do gênero exige qualidades diferentes do garotinho e da garotinha. Ela molda os corpos a fim de desenhar órgãos sexuais complementares. Ela prepara a reprodução, da escola até o Parlamento, industrializa-a (PRECIADO,2014, s/p) (grifo meu).

Viajando pelos fragmentos memorialísticos consigo exemplificar alguns momentos nos quais essa proteção da norma ficava evidente dentro da teatralidade familiar. Recordo-me, por exemplo, que em algum momento da minha infância meu pai e minha mãe fizeram a assinatura mensal da revista de nudez feminina Playboy. Naquela época meu pai acordava cedo, com céu ainda escuro, para trabalhar. Antes mesmo de se preparar para a lida, ele, juntamente com minha mãe [ainda sonolenta], me acordavam, me colocavam sentado no sofá e me entregavam, mês a mês, a nova edição da Playboy. Os dois ficavam em pé, lado a lado, e observando-me atentamente tentavam motivar minha curiosidade por aquele exemplar impresso, ainda envolto no plástico transparente. Diziam: "chegou presentinho novo, filhO!"; "Olha aquela artista famosa na capa da revista, filhO!"; "Mais uma pra coleção, filhO!"(...) Desconfiado que aquela teatralidade queria me dizer o que era "o certo", esboçava uma expressão de curiosidade e folheava cuidadosamente a revista tentando cumprir aquele misterioso papel. Não tinha a real noção do que aquelas imagens de mulheres nuas queriam me dizer, apenas observava-as ao mesmo tempo em que tentava identificar as expressões de aprovação ou desaprovação naqueles inquisidores rostos que me vigiavam.

Não sei ao certo o que motivou essas "ações de proteção", elas poderiam variar desde uma desconfiança a um medo brutal de que eu não seguisse 
a norma, poderiam ser motivadas por uma leitura que elxs faziam de minha subjetividade, corporalidade e ação, nesse caso, talvez, mais próximo de uma feminilidade do que de uma masculinidade coerentemente esperada do meu cisgênero $^{8}$ corpo; poderiam ser motivadas pelas leituras dxs outrxs [vizinhxs, familiares, amigxs...] que chegavam aos seus ouvidos. Muitas possibilidades! A única certeza, que às vezes escapava em algumas falas, era que elxs tentavam me ensinar a "ser homem".

Ao voltarmos para as cenas iniciais de "Fale com ela", quando "Café Muller" é apresentado a nós, espectadores, através do copioso choro de uma das personagens de Almodóvar, é inevitável não metaforizar sobre as produções discursivas em torno da minha infância. O interior do caótico e melancólico Café de Pina Bausch pode muito bem nos servir como imagem para entender a minha infância subjetiva e fisicamente violentada. Explico: na medida em que acompanhamos as dançarinas se chocando desgovernadamente pelas paredes do ambiente monocromático, de olhos fechados e com expressões faciais que denotam tristeza, é possível poetizar sobre o caos subjetivo produzido pelo abuso sexual e psicológico enfrentando pelas crianças. Ao mesmo tempo, quando refletimos sobre as reiterações constantes da heteronorma e sua produção constante de medos e ameaças, perpetradas pelas instituições sociais e seus discursos, é possível ouvir o ensurdecedor silêncio dos pedidos de ajuda que são neutralizados antes mesmo de irromper nos lábios e línguas das crianças violentadas. É como dançar no limbo do Café bauschiano, é como tentar produzir movimentos de saída do Café, mas o cinzento "caosfeicultor" te tragar novamente para dentro dele, é como assistir o mesmo Café sombrio através do olhar do personagem que chora copiosamente na platéia do

\footnotetext{
${ }^{8}$ Para uma compreensão mais abrangente do conceito de cisgeneridade eu recorro aos escritos de Jaqueline Gomes de Jesus (2012): "Compreendendo identidade de gênero como a 'profundamente sentida experiência interna e individual do gênero de cada pessoa, que pode ou não corresponder ao sexo atribuído no nascimento, incluindo o senso pessoal do corpo [...] e outras expressões de gênero, inclusive vestimenta, modo de falar e maneirismos', a cisgeneridade pode ser resumida como sendo a identidade de gênero daquelas pessoas cuja 'experiência interna e individual do gênero' corresponda ao 'sexo atribuído no nascimento' a elas. Em outras palavras, 'o termo 'cisgênero' é um conceito que abarca as pessoas que se identificam com o gênero que lhes foi determinado quando de seu nascimento, ou seja, as pessoas não-transgênero" (JESUS, 2012, p.8).
} 
filme. Ele apenas chora! Chora muito, pois não consegue ou não pode falar (Fig.3).

[Cenas almodovarianas 2] - Às margens de um rio, num dia ensolarado, um garoto de nome Ignácio, visivelmente constrangido como se estivesse fazendo algo a contragosto, canta a canção "Moon River" enquanto um padre, chamado Manolo, dedilha os acordes da música ao seu lado ${ }^{9}$. Enquanto isso outras crianças nadam, brincam e riem bastante, livres dos olhares de qualquer adulto. Os acordes do violão silenciam e por um instante ouvimos apenas a voz do garoto entoar a canção. Somos surpreendidos com um grito de "Nãããão!" e em seguida acompanhamos o garoto fugir de trás do arbusto, cair e bater a cabeça em uma pedra. Ao mesmo tempo, acompanhamos o padre sair de trás do mesmo arbusto, correr em direção ao garoto caído e ajeitar a sua batina, sugerindo para nós que estava quase desnudo na vegetação. A câmera dá um zoom no rosto do garoto e vemos escorrer sangue de sua testa (Fig.4), logo em seguida a voz em off do garoto diz: "O sangue escorreu e dividiu minha testa em dois. Senti que a mesma coisa iria acontecer com minha vida. Que ela seria sempre dividida e nada poderia fazer para evitar".

9 A cena citada faz parte do filme "Má Educação" (2004), do cineasta Pedro Almodóvar, e pode ser vista online a partir do endereço < https://goo.gl/QrZbnr >. Acesso em 21 jul. 2016. 
Figura 3 - Choro da personagem ao assistir Café Müller - cena do filme Fale com ela (2002)

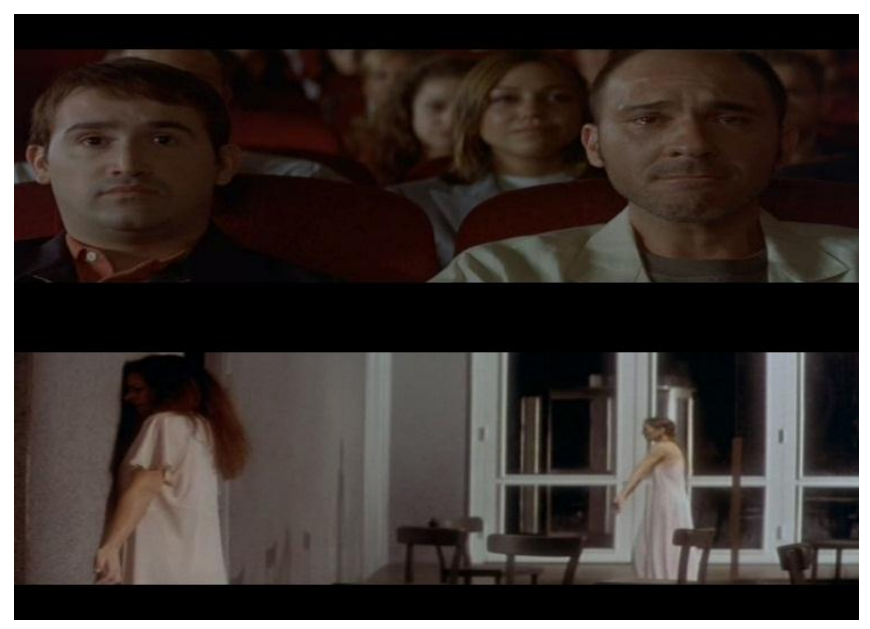

Figura 4 - Ignácio se machuca ao tentar fugir do adulto abusador cena do filme Má Educação (2003)

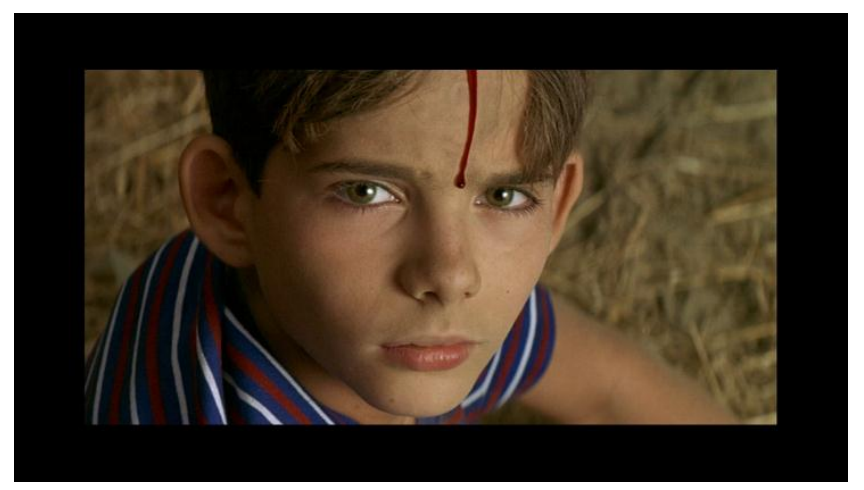

[Flashback] - Após se mudar do bairro da Liberdade, em Salvador (BA), Marcos, o meu vizinho abusador, foi morar num prédio estilo classe média do bairro de Brotas. Como as nossas famílias eram muito próximas, depois que ele e sua família estavam instalados em sua fantástica e curiosa residência, fomos visitá-los. Quando digo que a nova residência era curiosa e fantástica me refiro especificamente à arquitetura diferente da existente onde tínhamos sido criados, isto é, morávamos em uma avenida curta, com as casas perfiladas onde todos os vizinhos se conheciam. A nova residência de Marcos era num prédio alto, que tinha áreas diferentes, possuía elevador e um espaço de nome 
engraçado que, segundo os adultos, era destinado a nós crianças: o playground. Chegamos ao apartamento, nos alimentamos brevemente e enquanto os adultos conversavam na sala espaçosa fomos convidados, por Marcos, para conhecer o playground. Era muita aventura para as deslumbradas crianças: elevador, piscina ao longe, playground amplo e doses acolhedoras de brisa do entardecer! Não sei precisar ao certo por quanto tempo fiquei nesse paraíso, mas sei que aquela fantasia encerrouse para mim em questão de minutos. Marcos inventou que eu estava "perturbando" demais e disse que eu iria descer. Enquanto via as outras crianças brincando no recém-conhecido playground ele me puxava pela mão em direção ao elevador sob o pretexto de que não merecia brincar mais. O mais curioso era que eu não tinha feito absolutamente nada! Portanto não entendia o motivo de meu "castigo". Dentro daquele elevador [que até poucos minutos era um objeto astronomicamente engraçado, curioso e que nos levava a qualquer lugar em questão de minutos], sozinho com ele, senti pela primeira vez o pânico me paralisar. Não conseguia olhar para cima e meu rosto estava na altura de sua bermuda. Ele colocou seu "brinquedo peniano" para fora e forçou minha cabeça em direção a ele. Recuei bruscamente. O elevador chegou no andar solicitado, a porta abriu e eu torci para que alguém visse aquilo, mas ele já tinha guardado seu "brinquedo" e o vão estava vazio. Entramos em casa e ele relatou para os adultos que eu estava abusando demais lá embaixo e por isso ele resolveu me privar das brincadeiras. Se existisse uma câmera naquela sala esse seria o momento que o zoom, tal qual o personagem Ignácio, preencheria meu rosto com uma expressão de ódio, de raiva e, sobretudo, de impotência diante daquela violenta injustiça. Calei por medo! Calei por mudez física! Calei aos 8 anos de idade e só consegui falar sobre tudo isso aos 24 anos.

A relação paradoxal entre silêncio e explosão discursiva em contextos de violências pode ser refletida a partir de lugares distintos. Elegi os escritos de Michel Foucault (1988; 2010) e Judith Butler (2010) para me ajudar a refletir sobre as violências, nesse caso, mais especificamente, sobre as violências empreendidas em torno das subjetividades, entendidas, aqui, pelo viés da subalternidade: a infância e as performatividades de sexualidade e gênero que são dissidentes da heteronorma. A eleição dessxs autorxs é particularmente importante para o meu processo de escrita, pois põe em devir a própria narrativa de vida em que estive e na qual ainda estou inserido, isto é, quando exponho os fragmentos de meu abuso consigo fazê-los dialogar num processo de 
empoderamento sócio-político, reconstrução/ressignificação subjetiva e reflexão crítica da realidade social.

A incursão genealógica de Michel Foucault em torno do aparato discursivo sobre a sexualidade ocidental nos legou, entre outras coisas, pelo menos dois argumentos fundamentais para refletir sobre o [meu/nosso] abuso sexual infantil: o primeiro é a prática confessional, herdeira das técnicas de direção de consciência fundamentadas na cosmovisão cristãocêntrica e o segundo argumento versa sobre a natureza e aperfeiçoamento do olhar da instituição familiar burguesa em torno das corporalidades e subjetividades das crianças. Para Foucault (1988; 2010), a explosão discursiva em torno das sexualidades, facilitada pelos mecanismos confessionais das instituições sociais, foi a ferramenta que possibilitou a transformação do olhar da família nuclear burguesa sobre os corpos infantis. Se aceitamos o olhar proposto por Foucault é inevitável não nos questionarmos sobre a própria natureza desse "poder da família" em torno da infância: para quais propósitos sócio-políticos ele atua? Quais vozes podem falar dentro desse [novo?] cenário familiar, ou, mais importante ainda, quais vozes são obrigadas a silenciar em prol dessa nova lógica de atuação?

$\mathrm{Na}$ tentativa de refletir sobre as questões elencadas vou propor um jogo metafórico e acrônico axs nobres leitorxs. Trata-se de um jogo em que a personagem principal [peão ou peoa] é um sofá, móvel principal das salas de estar em "casas de família" e, curiosamente, o palco central da trama psicanalítica clássica. Para jogar o jogo eu disponho de dois dados, idênticos, nos quais todas as faces têm o valor um. Lanço os dados. Qualquer lançamento, somados, resultará dois. Ao avançar sobre o tabuleiro, na primeira jogada, a mensagem que lemos/ouvimos é: "O abuso sexual só existiu porque as figuras de pai [1] e mãe [1] não existiram efetivamente em sua infância! Revés: Espere uma [vida] rodada". Enquanto espero a rodada permito-me digredir.

$8 .$.

No momento em que decidi falar sobre o meu abuso sexual publicamente, tentando minimizar o adoecimento psíquico ${ }^{10}$ resultante

10 Adoecimento psíquico, aqui, tem mais a ver com processos [conscientes ou inconscientes] que paralisam as vivências dos indivíduos, do que com categorias médicas e patológicas do rol de doenças catalogáveis do menu das ciências dedicadas à psique humana. 
da clausura dolorosa e silenciosa da violência sofrida na infância, eu iniciei uma análise psicanalítica, de viés freudiano clássico, com um profissional. Em aproximadamente oito meses de encontros semanais consegui nomear a violência como "abuso", consegui ressignificar a culpa subjetiva que nutri durante anos por julgar ter "seduzido" o meu abusador e consegui entender o quão violenta é a experiência do abuso sexual. O que não consigo entender até hoje é a natureza da afirmação que ouvi em uma das sessões: "O abuso sexual só existiu porque as figuras de pai e mãe não existiram efetivamente em sua infância!". Mesmo compreendendo que as consequências de tal afirmação encontram eco em nossas performances e tabus sociais, que tendem a supervalorizar e até mesmo idealizar um modus operandi de ser pai e mãe - que seria responsável, portanto, pela proteção e cuidado da infância -, na medida em que transpomos tal afirmação para a própria vivência e subjetividade da criança que fui, sofredora, portanto, do abuso, um curto-circuito se instala de tal forma que uma espiral de silêncio se estabelece novamente sobre a violentada subjetividade infantil. Isto é, mas onde será que o abusador está nessa violenta trama psicanalizada? Se para esse meu analista xs culpadxs do meu abuso foram xs meus genitorxs [ou a inexistência delxs], o próprio discurso psicanalítico excluiu a materialidade do abusador ${ }^{\mathbf{1 1}}$.

A constatação dessa exclusão discursiva do meu algoz pela trama psicanalítica mais afinada com a psicanálise freudiana clássica foi justamente a mola propulsora que me instigou a refletir sobre o abuso sexual, nesse caso, mais especificamente, sobre como a discursividade incide violenta e silenciosamente sobre uma corporalidade entendida como masculina. Ou, em outras palavras: por que o abuso sexual em garotos é tão perturbador e ao mesmo tempo tão ocultado, silenciado e invisibilizado nos discursos e práticas das instituições sociais? ${ }^{12}$

\footnotetext{
${ }^{11}$ É importante ressaltar que me refiro aqui não à materialidade e corporalidade dos meus pais, mas sim à discursividade e produção de uma LEI superior responsável pela regulação de nossas subjetividades. No discurso psicanalítico essa discursividade se refere diretamente àquilo que produz em nossas subjetividades [não deslocadas das relações da cultura] a noção normativa de certo e errado, em territórios culturais. $\mathrm{Na}$ psicanálise clássica essa lei superior é produzida a partir do Complexo de Édipo, isto é, na relação direta e libidinalmente prazerosa, ou não, entre a criança e as figuras que cumprem o papel social da família.

${ }^{12}$ Essa pergunta encontra justificativa em dados estatísticos realizados por órgãos de proteção à criança e adolescente ao redor do mundo e, também, em textos acadêmicos 
Ao voltarmos para o último capítulo da "História da sexualidade volume 1" (1988), intitulado "Direito de morte e poder sobre a vida", lemos a reflexão de Michel Foucault a respeito da transformação dos mecanismos de poder relacionados à gestão da vida. A célebre passagem do autor coroa tal transformação: "Pode-se dizer que o velho direito de causar a morte ou deixar viver foi substituído por um poder de causar a vida ou devolver à morte" (FOUCAULT, 1988, p.150). De forma rápida, pois não é o objetivo desse trabalho demonstrar a gênese dessas transformações, resumo, a partir de Foucault, que na época clássica, e antes dela, na época "antiga e absoluta", o poder era legitimado por um indivíduo soberano, que tinha "direito de apreensão das coisas, do tempo, dos corpos e, finalmente, da vida", culminando, portanto, "com o privilégio de se apoderar da vida para suprimi-la" (FOUCAULT, 1988, p.148). Já partir do século XVII, tais mecanismos, agora transformados, "apresentam-se como complemento de um poder que se exerce, positivamente sobre a vida, que empreende sua gestão, sua majoração, sua multiplicação, o exercício, sobre ela, de controles precisos e regulações de conjunto" (FOUCAULT, 1988, p.149). Acionando os argumentos de Ariès (2014), é curioso constatar que a própria noção de infância ganha força, também, a partir do século XVII.

Ao olhar para as transformações desses mecanismos de poder, Foucault (1988) elenca dois "pólos de desenvolvimento" a partir dos quais a gestão da vida e da morte, e por conseqüência dos indivíduos que estão submetidas a elas [isto é, todxs nós], irá se apresentar ao processo histórico. O primeiro pólo centrou-se no "corpo como máquina: no seu adestramento, na ampliação das suas aptidões, na extorsão de suas forças, no crescimento paralelo de sua utilidade e docilidade, na sua integração em sistemas de controle eficazes e econômicos" (p.151), ou naquilo que o autor chama de "disciplinas anátomo-política do corpo humano". O segundo pólo, que se forma por volta da metade do século XVIII, centrou-se no "corpo-espécie", no corpo "transpassado pela

que refletem os abusos em corporalidades lidas como masculinas. Dentre eles destaco aqui: 1 - Ocultos a plena luz. Un análisis estadístico de la violencia contra los niño (UNICEF, 2014). Disponível em <http://goo.gl/0cG3ig> Acesso em: 22 ago. 2016; 2 - Sistema de Vigilância de Violências e Acidentes (Viva): 2009, 2010 e 2011 (BRASIL. MINISTÉRIO DA SAÚDE, 2013). Disponível em 〈http://goo.gl/zxaryc> Acesso em: 22 de ago. 2016; 3 - Violência sexual contra meninos: dados epidemiológicos, características e consequências. (HOHENDORFF, Jean Von; HABIGZANG, Luísa Fernanda; KOLLER, Silvia Helena. 2012) Psicol. USP, São Paulo, v.23, n.2, p. 395-416. Disponível em <http://goo.gl/8phSHl> Acesso em 22 ago. 2016. 
mecânica do ser vivo e como suporte dos processos biológicos", aqui "a proliferação, os nascimentos e a mortalidade, o nível de saúde, a duração da vida, a longevidade, com todas as condições que podem fazê-los variar" serão o foco de sua análise. Nesse segundo pólo, para o autor, "tais processos são assumidos mediante toda uma série de intervenções e controles reguladores, isto é, uma bio-política da população" (p. 151152). A partir do desenvolvimento desses pólos, o autor arremata: "Uma sociedade normalizadora é o efeito histórico de uma tecnologia de poder centrada na vida." (FOUCAULT, 1988, p.157), isto é, agora as instituições sociais agirão a partir do "direito de fazer viver e de deixar morrer" (FOUCAULT, 2010, p. 202).

Após as reflexões de Foucault e concentrar um olhar na instituição social "família", no discurso psicanalítico teatralizado em minha análise e, priorizar, também, um recorte específico em relação às questões de sexualidade e gênero, caras a esse trabalho, posso refletir melhor sobre as questões elencadas acima: para quais propósitos sociopolíticos esses mecanismos de poder atuam? Quais vozes podem falar dentro desse cenário familiar e terapêutico?

Tais questionamentos encontram ecos naquilo que Judith Butler (2010) vai nomear, a partir das autoras Monique Wittig e Adrienne Rich, como "matriz heterossexual" ou "heteronorma". Para Butler (2010), esses conceitos designam a "grade de inteligibilidade cultural por meio da qual os corpos, gêneros e desejos são naturalizados", ou melhor, caracteriza o

[...] modelo discursivo/epistemológico hegemônico da inteligibilidade do gênero, o qual presume que, para os corpos serem coerentes e fazerem sentido (masculino expressa macho, feminino expressa fêmea), é necessário haver um sexo estável, expresso por um gênero estável, que é definido oposicional e hierarquicamente por meio da prática compulsória da heterossexualidade" (BUTLER, 2010, p. 216).

Então, pensando a partir do argumento foucaultiano de que a norma é um reflexo das tecnologias de poder centrados na vida e pensando, também, o argumento butleriano de que as instituições sociais, a linguagem e a política se constituem e agem a partir de uma norma heterossexista, é inegável que o discurso psicanalítico clássico - de referência estritamente freudiana - proferido pelo meu terapeuta, 
esbarraria em tais lógicas. Explico-me: se em tempos remotos vivíamos uma "sociedade de sangue" ("sanguinidade") na qual a "honra da guerra e medo das fomes, triunfos da morte, soberano com gládio, verdugos e suplícios, o poder falar através do sangue era uma realidade com função simbólica", a partir do século XVI entramos em uma "sociedade do sexo, ou melhor, de sexualidade" na qual "os mecanismos do poder se dirigem ao corpo, à vida, ao que a faz proliferar, ao que reforça a espécie, seu vigor, sua capacidade de dominar, ou sua aptidão para ser utilizada", isto é, "o poder fala da sexualidade e para a sexualidade" (FOUCAULT, 1988, p.160-161). Em resumo: "Foram os novos procedimentos do poder, elaborados durante a época clássica e postos em ação no século XIX, que fizeram passar nossas sociedades de uma simbólica do sangue para uma analítica da sexualidade" (FOUCAULT, 1988, p.161). A psicanálise, enquanto disciplina que se origina no alvorecer do século XIX, que se ocupa do inconsciente desejoso e estrutura-se em torno de uma analítica da sexualidade, ao buscar uma explicação fixa e plausível para a violência sexual infligida sobre o meu cisgênero corpo e ao tentar dar coerência à sua própria produção discursiva e teórica, não tardaria em reproduzir o discurso heteronormativo.

"O abuso sexual só existiu porque as figuras de pai e mãe não existiram efetivamente em sua infância" é uma afirmação duplamente violenta: ao desviar o protagonismo do meu abusador para as figuras de minha família, esse discurso psicanalítico produz um movimento que tenta resolver um adoecimento subjetivo [motivado pela violência] apoiandose em uma narrativa que repete e reafirma a matriz heterossexual. Isto é, mesmo que Marcos tenha cometido o abuso [e tal conjectura está nas entrelinhas do discurso do terapeuta], a culpa recai sobre a não vigilância e a, pretensa, negligência do meu pai e de minha mãe. Em outras palavras, o abusador mantém sua inteligibilidade (de gênero e de "adultibilidade") perante as instituições sociais, pois o silêncio a que sou impelido a conviver [por temer as represálias dessa mesma heteronorma], é o cenário da reiteração violenta do abuso. A afirmação do terapeuta é violenta, também, pois ao inquirir o Ramon infante, num flashback cinematográfico, produz sentimentos de raiva e decepção. Ou seja, ao recuperar fragmentos violentos dessa infância [perpetrados por um indivíduo], o terapeuta libera o abusador de suas ações e traz ao palco psicanalítico as figuras do pai e da mãe para dar sentido à sua narrativa edipianizada. 
É o que podemos apreender da leitura de Foucault (1988) e Butler (2010). O primeiro, ao analisar as transformações dos mecanismos de poder, afirma:

[na analítica da sexualidade] pode-se a partir deste mesmo fim do século XIX [que é justamente o momento da potencialização do discurso psicanalítico], seguir o esforço teórico para reinscrever a temática da sexualidade no sistema da lei, da ordem simbólica e da soberania. É uma honra política para a psicanálise ter suspeitado (e isto desde o seu nascimento...) do que poderia haver de irreparavelmente proliferante nesses mecanismos de poder que pretendiam controlar e gerir o quotidiano da sexualidade: daí o esforço freudiano [...] para dar à sexualidade a lei como princípio, - a lei da aliança, da consanguinidade interdita, do Pai-Soberano, em suma, para reunir em torno do desejo toda a antiga ordem do poder (FOUCAULT, 1988, p.163-164) (grifos meus).

Judith Butler (2010), refletindo sobre a origem de um indivíduo para a teoria feminista [discussão que não vem ao caso aqui], nos leva à seguinte passagem: "A história das origens é, assim, uma tática astuciosa no interior de uma narrativa que, por apresentar um relato único e autorizado sobre um passado irrecuperável, faz a construção da lei parecer uma inevitabilidade histórica" (p. 64). Nesse sentido, o discurso psicanalítico proferido no setting terapêutico ao qual participei atua a partir da lógica de reprodução e reiteração da heteronorma, ou melhor, ele mantém a subjetividade abusadora em uma zona de conforto, sem inquirir sua lógica, sem questionar suas artimanhas e, portanto, silenciaa socialmente [para usar a metáfora da fala psicanalítica], ao mesmo tempo que a faz falar apenas dentro do consultório e deitada sobre o nosso personagem "sofá".

Lanço os dados novamente! Resultado: 2- Avanço duas casas e leio no tabuleiro: "Quais vozes podem falar dentro desse cenário?". Olho para meu "peão-sofá". O tabuleiro, numa bifurcação territorial, me oferece dois caminhos únicos e distintos. Preciso decidir! Um caminho, por ser o mais curto em extensão, mais rápido em relação à chegada e o mais rentável no nosso Banco Imobiliário®/Monoply® Subjetivo, "conserva" uma trilha de reprodução heteronormativa, coerentemente harmonizada com a família nuclear burguesa e com os discursos/práticas cristãocêntricas de culpabilidade e confessionalidade. O segundo caminho, por apresentar uma extensão ampla na qual as casas 
apresentam diversificadas mensagens de sorte/revés e interpelações constantes axs jogadorxs, nos permite uma "multiplicidade de jogadas", mas não nos leva a chegada tão facilmente.

Reflito: quero chegar logo ou quero continuar jogando? Xs corpxs doem, as fomes se intensificam, a vontade incessante de fazer qualquer outra coisa que não seja jogar impera, a vontade de se render ao caminho mais curto é muito sedutora. O tempo está passando e preciso decidir! Olho ao redor da sala onde jogo o jogo e instantaneamente uma cena que está passando na televisão me captura: é uma cena do filme "Átame" (1990) ${ }^{13}$. Nela, três personagens, dentro de um carro, dirigem por uma estrada deserta e ensolarada, ao mesmo tempo em que decidem como irão levar a vida a partir daquele momento. Após vaticinarem, uma das personagens diz: "bem, vou por um pouquinho de música!". A partir deste momento já não sei mais se estou no filme ou se o filme tornou-se a própria realidade, apenas permito-me [enquanto decido qual caminho pegar] ouvir e cantar, junto com as personagens, a música que toma conta do veículo:

$$
\begin{aligned}
& \text { Cuando pierda todas las partidas } \\
& \text { Cuando duerma con la soledad } \\
& \text { Cuando se me cierren las salidas } \\
& \text { Y la noche no me deje en paz } \\
& \text { Cuando sienta miedo del silencio } \\
& \text { Cuando cueste mantenerse en pie } \\
& \text { Cuando se rebelen los recuerdos } \\
& \text { Y me pongan contra la pared }
\end{aligned}
$$

Resistiré, erguido frente a todo

Me volveré de hierro para endurecer la piel

\footnotetext{
${ }^{13}$ A cena pode ser conferida pelo link <http://goo.gl/DXj9NC〉. Acesso em: 06 set. 2016. 
Y aunque los vientos de la vida soplen fuerte

Soy como el junco que se dobla,

Pero siempre sigue en pie

Resistiré, para seguir viviendo

Soportaré los golpes y jamás me rendiré

Y aunque los sueños se me rompan en pedazos

Resistiré, resistiré

Cuando el mundo pierda toda magia

Cuando mi enemigo sea yo

Cuando me apuñale la nostalgia

Y no reconozca ni mi voz

Cuando me aminace la locura

Cuando en mi moneda salga cruz

Cuando el diablo pase la factura

Se alguna vez me faltas tu

Resistiré

Duo Dinâmico, na música "Resistiré" (1988)

$\mathrm{Na}$ tentativa de descobrir "quais vozes podem falar dentro desse jogo" decido continuar jogando. Chegar rapidamente ao fim apenas cessará minha curiosidade, mas continuar jogando me manterá no jogo. Rolam os dados. 
[Cenas almodovarianas 3] - Em um cemitério, num dia ensolarado e de uma ventania ensurdecedora, várias mulheres limpam as sepulturas, entre elas está Raimunda, Paula e Sole, respectivamente uma mãe, uma filha e uma tia. Ao fundo ouvimos a canção "Las Espigadoras", da opereta “La Rosa del Azafrán”. Em setembro de 2009, numa entrevista para o periódico cultural Serafina, da Folha de São Paulo, Pedro Almodóvar, quando questionado sobre uma música predileta, responde:

Uma das primeiras canções de que me lembro é uma música que minha mãe e suas amigas cantavam enquanto lavavam roupas no rio. Devia ter uns quatro ou cinco anos naquela época. A canção aparece em 'Volver' e se chama 'Las Espigadoras', da opereta 'La Rosa del Azafrán' (GRANATO, 2009, p.53).

Paula, uma adolescente de quatorze anos, ao observar o cemitério cheio de mulheres cuidando dos seus mortos, fala, curiosamente espantada, para sua mãe e sua tia: "Quantas viúvas têm aqui!". Ao dirigirem-se para o carro Paula questiona: "Mamãe, é verdade que as pessoas vêm arrumar seu próprio túmulo?". Raimunda responde: "Sim, aqui é costume. Se comprar primeiro seu terreninho vão cuidar dele em vida. Como se fosse um chalé.". "Que loucura, tia!", responde Paula. "São costumes!", retribui Sale.

Frederic Strauss (2008) questiona Pedro Almodóvar: "Ressuscitar o passado era seu objetivo principal em Volver?". O cineasta responde assim:

Era a própria ideia do filme antes mesmo de eu começar a rodá-lo: redescobrir as sensações do meu passado. Eu não sabia se isso ia acontecer, mas a ideia se tornara uma realidade. Reencontrei em La Mancha [região da Espanha onde o cineasta nasceu] as lembranças que eu deixara lá, como aquela visão do cemitério cheio de mulheres cuidado das sepulturas. Fiquei muito satisfeito com esse primeiro plano do filme (Fig 5). Vemos as mulheres da aldeia e percebemos que não são figurantes: elas continuam a ser exatamente como as da minha infância. Não há no filme personagem de criança, mas o ponto de vista é o meu quando era pequeno. (STRAUSS, 2008, p.283) [grifo meu].

É a partir desses fragmentos que [re]inicio a etapa mais derradeira dessa ex-cripta. 
Figura 5 - Sepulturas no início do filme Volver (2005)

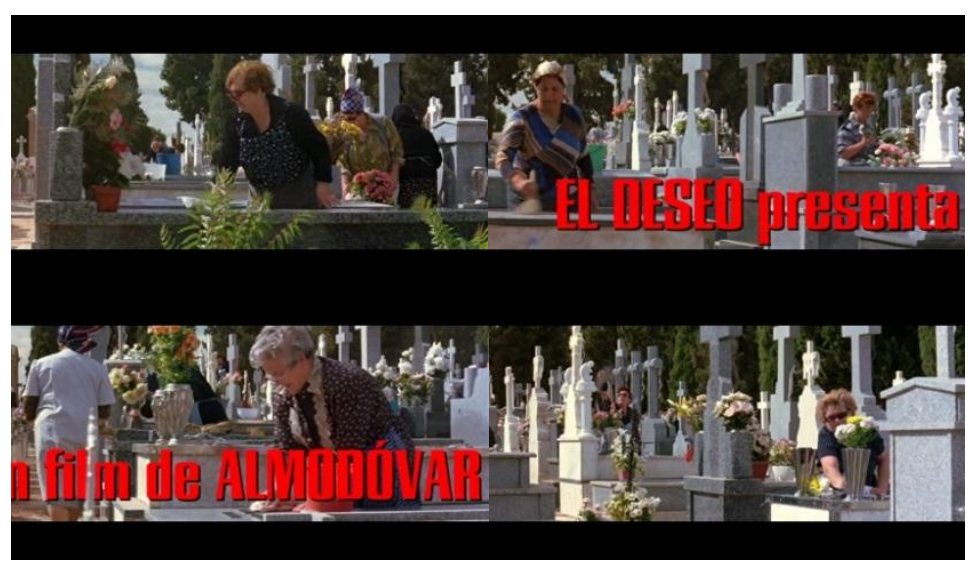

O filme "Volver", lançado em 2005, ano que completei quinze anos de idade, aglutina todas as experiências subjetivas em relação às normas de sexualidade e gênero que venho refletindo ao longo dos anos. Não é por acaso que nesse mesmo ano, num épico de guerra familiar e sociopolítica, tornei pública a minha orientação sexual e, desde então, tenho seguido cada vez mais a reverberar tais posicionamentos identitários. A película almodovariana gira em torno da loucura, dos segredos familiares e das experiências místicas com os mortos e, para além disso, o abuso sexual é também o personagem mais intrigante desse filme. Duas gerações marcadas pela violência do abuso físico e marcadas pela violência do silêncio a que são obrigadas a conviver.

Raimunda, a mãe, vivida pela atriz Penélope Cruz, foi violentada pelo seu pai e através desse abuso engravidou de Paula. Paula, vivida pela atriz Yohana Cobo, também é violentada, anos mais tarde, pelo seu pai de criação, Paco (Antonio de La Torre). Mãe, filha, mãe-irmã, um cruzamento sanguíneo que serve de personagem e cenário para as reflexões que venho tecendo. Permitam-me, xs estimadxs leitorxs, uma paródia do famoso poema "Quadrilha" (1930), de Carlos Drummond de Andrade, para dar conta, rapidamente, do enredo do filme:

Raimunda era filha de Irene que era casada com um pai que não é nomeado 
O sem nome violenta Raimunda que engravida de seu pai que é um abusador

Irene, ao descobrir a trama, assassina-o e some da história.

Paula era filha-irmã de Raimunda que era casada com Paco

Paco violenta Paula que esfaqueia seu abusador, matandoo

Irene dá fim ao abusador de Raimunda que dá fim ao abusador de Paula

Irene, Raimunda e Paula são personas de Pedro

que tinha entrado na história de Ramon

(QUATRILHA, RAMON, 2016)

A cena que mais me interessa aqui é justamente a morte de Paco, abusador de Paula. Ela não é filmada, mas reconstruo-a através dos fragmentos discursivos de Paula. Assistamos, pois: Paula, visivelmente nervosa, aguarda sua mãe Raimunda na parada de ônibus na esquina de casa. Ao descer do coletivo sua mãe questiona: "Há algo de errado?", Paula mantém-se calada e apreensiva. Ao entrarem no vão do prédio onde moram, Raimunda torna a questionar sua filha: "Onde está seu pai?" e Paula, criando coragem, diz: "Está na cozinha!". Já dentro de casa Raimunda grita horrorizada ao encarar o corpo ensanguentado e inerte no chão da cozinha (Fig. 6).

Figura 6 - Raimunda encara o corpo do abusador de sua filha - cena do filme Volver (2005) 


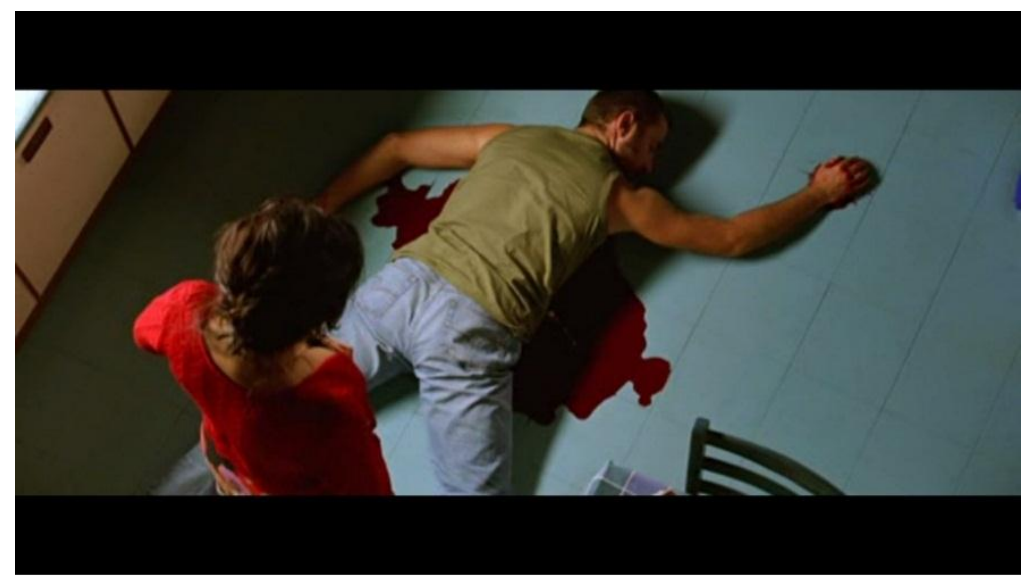

A partir daí ouvimos o diálogo entre mãe e filha:

Raimunda: O que aconteceu?

Paula (chorando, mas com expressão de nojo e raiva): Estava na cozinha, de costas e de repente papai ficou em cima de mim. Estava bêbado! Perguntei, aos gritos, o que estava fazendo e ele disse que não era meu pai. Empurrei e tirei ele de cima de mim, mas se levantou e voltou a me abraçar. Voltei a empurrá-lo. Desabotoou a calça, dizendo que aquilo não era ruim e ele não era meu pai. Abri a gaveta e peguei uma faca e o ameacei, mas só para assustar ele. Fez-me pouco caso, disse que eu não seria capaz e se jogou para cima de mim.

Raimunda abraça sua filha e ambas choram juntas.

Com folhas de papel Raimunda estanca o sangue do abusador (Fig. 7) e logo em seguida lava a faca utilizada na morte do mesmo (Fig. 8).

Figura 7 - Folhas de papel estancam o sangue do abusador - cena do filme Volver (2005) 


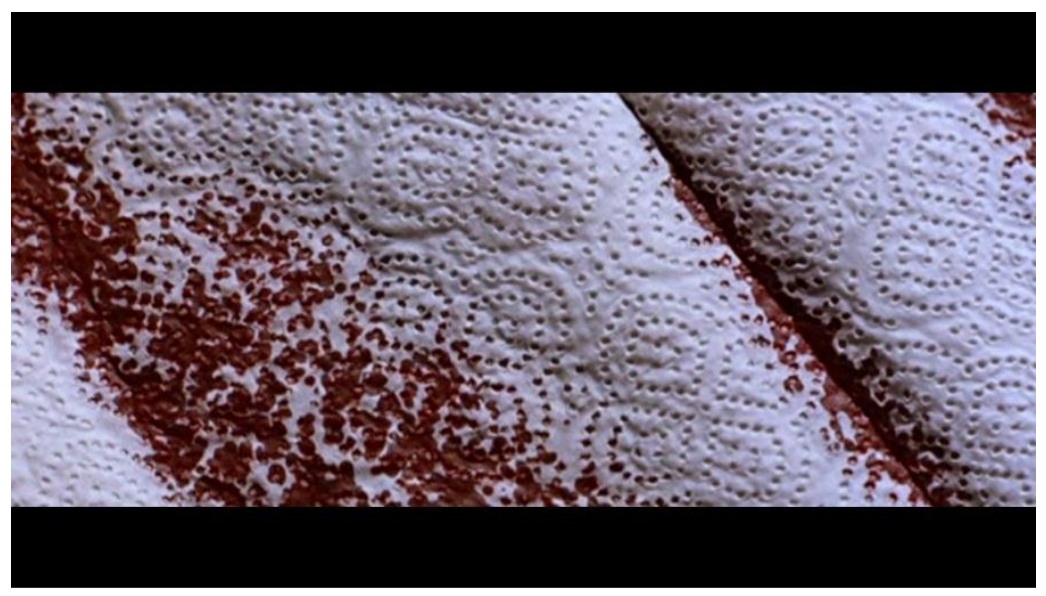

Figura 8 - Raimunda lava a faca - cena do filme Volver (2005)

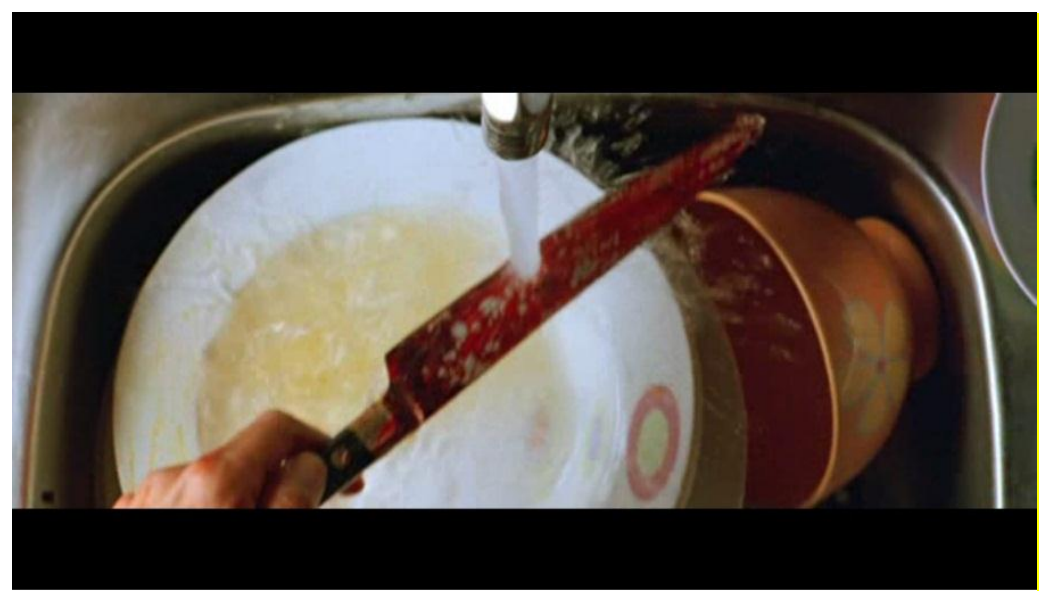

Em determinado momento Raimunda fala para Paula: "Volte ao seu quarto, Paula!" e ela responde "Não, quero estar contigo!". Duas gerações se juntam para vingar o abuso sexual que sofreram em vida. Duas gerações que agem ao sabor do tempo na tentativa de confrontar seus algozes. Duas gerações que usam as armas disponíveis para enfrentar o julgo opressor daqueles que lhes tomam seus corpos de assalto e que se beneficiam da cumplicidade dos discursos heteronormativos.

Depois de conservar o corpo do abusador de sua filha, por algum punhado de dias num gélido freezer, Raimunda vai às margens de um rio e enterra o eletrodoméstico, com o corpo dentro, em sua margem. 
Algum tempo depois, ao visitar o lugarejo juntamente com sua mãe Irene, sua irmã Sole e sua filha Paula, Raimunda fala: "Esse era o lugar preferido de seu pai: o rio!" e Paula responde, depois de olharem-se cumplicimente: "Gosto que descanse aqui!".

Em "Fale com ela", a personagem Alicia, mesmo desenganada pelos médicos, reage contra seu abusador ao acordar do coma e, cumprindo o desejo explicitado no autógrafo de Pina Bausch, "vence os obstáculos e começa a dançar"; Em "Má educação", Ignácio escreve uma história, como forma de denúncia, inspirada nos anos que passou sobre o julgo dos abusos físicos do padre Manolo e de todas as violências sofridas dentro do colégio católico em que estudou; em "Volver", Irene vinga-se do pai e abusador de sua filha Raimunda ao tocar fogo na casa onde ele estava dormindo; já Paula reage contra seu violentador matando-o com facadas em plena cozinha; Raimunda, por sua vez, reage contra seu abusador e contra o abusador de sua filha ao assumir para si a responsabilidade pela morte física e subjetiva de alguém capaz de abusar sexualmente de outro alguém. Não gostaria de forçar e nem dar a entender que estou forçando os argumentos fílmicos na tentativa de encaixar interpretações, mas percebam, poéticxs leitorxs, o abuso sexual, tematizado nos três filmes de Almodóvar usados aqui, produz reações no cenário sociopolítico da própria narrativa, ao mesmo tempo em que possibilitam, a nós espectadores, elucubrar outros tantos cenários e mensagens que se aplicam ou aproximam-se da nossa cotidianidade nada cinematográfica. Entre tais cenários e mensagens a "reação ao abuso e ao abusador" aparecem como motes plenamente possíveis. Naveguemos, juntxs.

[Cena escrita em rios] - Ao voltar às margens do rio, sob os acordes dissonantes de Marcos - o meu abusador -, assumo o canto e entôo, tal qual Ignácio, a canção "Moon River". "O sangue escorreu e dividiu minha testa em dois. Senti que a mesma coisa iria acontecer com minha vida. Que ela seria sempre dividida e nada poderia fazer para evitar". A desesperança que emerge das palavras de Ignácio encontra eco justamente nas violências cotidianas a que as crianças que sofrem abuso sexual são empurradas a conviver. Um mix de vergonha, por ter a sua corporalidade invadida, tomada de si, ao mesmo tempo uma dose brutal de impotência em relação à discursividade do adulto que, mediante violências subjetivas, faz com que o silêncio impere e o medo paralise. 
No terceiro volume de sua "História da sexualidade - o cuidado de si" (1985), acompanhamos a genealogia de Michel Foucault dar conta dos processos discursivos que se ocuparam de analisar, revelar, classificar, interrogar e cooptar os mecanismos que se relacionam diretamente com a produção e a reprodução de uma dada moral em torno da sexualidade ou da moral dos prazeres. Nesse sentido, ele cita três movimentos, que se deram ao longo dos séculos e que ajudaram a complexificar o relacionamento entre os indivíduos e as normas do biopoder, centradas, portanto, naquilo que ele nomeou de analítica da sexualidade. Os movimentos são assim descritos:

a atitude individualista, caracterizada pelo valor absoluto que se atribui ao indivíduo em sua singularidade e pelo grau de independência que lhe é atribuído em relação ao grupo ao qual ele pertence ou às instituições das quais ele depende; a valorização da vida privada, ou seja, a importância reconhecida às relações familiares, às normas de atividade doméstica e ao campo dos interesses patrimoniais; e, finalmente, a intensidade das relações consigo, isto é, das formas nas quais se é chamado a se tomar a si próprio como objeto de conhecimento e campo de ação para transformar-se, corrigir-se, purificar-se, e promover a própria salvação (FOUCAULT,1985, p.48) (grifos meus).

Para o autor não há uma cronologia exata para o desenvolvimento de tais movimentos, isto é, eles se deram ao longo dos séculos e estiveram muitas vezes amalgamados. Acontece que a partir do apogeu no século XIX vemos irromper no cenário político e social toda a potência dos três movimentos, ou melhor, vemos "o desenvolvimento daquilo que se poderia chamar uma 'cultura de $\mathrm{si}^{14}$, na qual foram intensificadas e valorizadas as relações de si para consigo" (FOUCAULT,1985, p.49). Levando em conta a dinâmica dos protagonismos sociais, as infinitas possibilidades de interpelações promovidas pelas instituições e outrxs indivíduos e, por último, que a temporalidade dos contextos sóciopolítico são inerentes às nossas formações enquanto indivíduos, Foucault nos diz: "não há idade para se ocupar consigo" (1985, p.54).

14 "Pode-se caracterizar brevemente essa 'cultura de si' pelo fato de que a arte da existência - a techne tou biou sob as suas diferentes formas - nela se encontra dominada pelo princípio segundo o qual é preciso 'ter cuidados consigo'; é esse princípio do cuidado de si que fundamenta a sua necessidade, comanda o seu desenvolvimento e organiza sua prática" (FOUCAULT, 1985, p.49). 
Nesse sentido, a que dedicar tempo e atenção, também, a toda uma série de discursos e práticas que permitem o exercício desse cuidado de si:

Esse tempo não é vazio: ele é povoado por exercícios, por tarefas práticas, atividades diversas. Ocupar-se de si não é uma sinecura. Existem cuidados com o corpo, os regimes de saúde, os exercícios físicos sem excesso, a satisfação tão medida quanto possível, das necessidades. Existem as meditações, as leituras, as anotações que se toma sobre livros ou conversações ouvidas, e que mais tarde serão relidas, a rememoração das verdades que já se sabe mas de que convém apropriar-se ainda melhor. [...] em torno dos cuidados consigo toda uma atividade de palavra e de escrita se desenvolveu, na qual se ligam o trabalho de si para consigo e a comunicação com outrem (FOUCAULT, 1985, p. 56-57).

Sintetizando a complexidade dessa cultura/cuidado de si, o autor chama atenção: "Tem-se aí um dos pontos mais importantes dessa atividade consagrada a si mesmo: ela não constitui um exercício da solidão, mas sim uma verdadeira prática social. E isso, em vários sentidos." (FOUCAULT, 1985, p.57). O sentido que nos interessa mais especificamente aqui são os sentidos atribuídos à prática de uma determinada norma de sexualidade e gênero, afinadas com a heteronormatividade analisada por Butller, e que potencializam a abjeção, "grotescabilidade" ou "anormalidade" daquelxs que não seguem tal norma. Foucault, afinado com nossa reflexão, nos alerta:

O prazer sexual enquanto substância ética é ainda e sempre uma ordem de força - da força contra a qual é preciso lutar e sobre a qual o sujeito deve assegurar sua dominação; mas nesse jogo da violência, do excesso, da revolta e do combate, o aceno é colocado cada vez mais naturalmente na fraqueza do indivíduo, na fragilidade, na necessidade em que ele se encontra de fugir, de escapar, de se proteger e de se manter abrigado. A moral sexual exige, ainda e sempre, que o indivíduo se sujeite a uma certa arte de viver que define os critérios estéticos e éticos da existência; mas essa arte se refere cada vez mais a princípios universais da natureza ou da razão, aos quais todos devem curvar-se e da mesma maneira, qualquer que seja seu status (FOUCAULT, 1985, p.72).

Esse caminho, de olhar atento, me coloca cara a cara com outro escrito contemporâneo ao terceiro volume da "História da sexualidade": é o texto "A escrita de si" (2006), de autoria também foucaultiana. Nele, 
empreendendo o mesmo esforço genealógico e refletindo mais detidamente sobre a escrita como uma técnica que pertence ao projeto de cultura/cuidado de si, o autor nos escreve: "Nenhuma técnica, nenhuma aptidão profissional podem adquirir-se sem exercício; também não se pode aprender a viver - a tekne tou biou - sem uma askesis, entendida como um adestramento de si por si mesmo" (FOUCAULT, 2006, p. 146).

Por isso mesmo que, ao decidir voltar à margem do meu rio de memórias, eu sabia que deveria exercitar o próprio exercício da viagem. Na acepção de Guacira Lopes Louro (2004), x viajante não é aquelx que vai gradativamente "tomando posse de si mesmo", mas, na medida mesmo em que viajam a ideia de desenraizamento, de deslocamento, trânsito, desterritorialização se agregam à própria ideia de viajar. Em resumo:

[...] não há um lugar de chegar, não há destino pré-fixado, o que interessa é o movimento e as mudanças que se dão ao longo do trajeto. [...] os sujeitos podem até voltar ao ponto de partida, mas são, em alguma medida, 'outros' sujeitos, tocados que foram pela viagem. Por certo também há, aqui, formação e transformação, mas num processo que, ao invés de cumulativo e linear, caracteriza-se por constantes desvios e retornos sobre si mesmo, um processo que provoca desarranjos e desajustes, de modo tal que só o movimento é capaz de garantir algum equilíbrio ao viajante. (LOURO, 2004, p.13)

VOLVER é a metáfora mais precisa para dar conta justamente dessa viagem a que me propus fazer. Como palavra ela comporta a ideia do retorno, de uma viagem no tempo passado; de um retorno à infância com olhares de adulto; de uma contação de história que retroage; de uma estória que alimenta a imaginação de infantes e adultos; de uma pergunta que nos desestabiliza na hora mesma em que é proferida: e se? [nesse caso aplicada sempre a uma situação anterior: e se eu fizesse algo? e se eu falasse? e se eu não calasse? e se eu me recusasse? e se...?]. VOLVER, também, refere-se ao título da película almodovariana na qual a própria personagem abusada reage a partir de uma ação lida socialmente como de legítima defesa, portanto, que comporta toda a carga de justiçamento, do olhar benevolente das Leis. VOLVER, não enquanto palavra, mas enquanto sonoridade da língua portuguesa, em território brasileiro, nos possibilita, também, uma atitude que se aproxima do ato de ver algo: VOU VER! Aqui, nessas linhas, vou ver o 
rosto do meu abusador, vou ver a corporalidade dele, vou ver como estive envolvido em sua discursividade abusadora e como estive "em suas mãos", vou ver como as instituições sociais foram cúmplices do abuso que sofri. Vou ver, também, como a minha história, longe de ser inédita, mantém íntima relação com outras tantas histórias de violência infantil. Vou ver os acordes corretos, vou ver o tom, vou ver o som, vou ver o olho do meu abusador, encarando-o, enquanto canto às margens do rio.

Em determinado momento do filme "Volver", numa festa promovida num restaurante, Paula fala com Raimunda: "Eu nunca a ouvi cantar, mamãe!", ela devolve "Sério mesmo, minha filha? E você gostaria?" e Paula, esperançosa, "Que coisa, claro mamãe!". A partir daí a atriz Penélope Cruz, intérprete de Raimunda, dirige-se aos tocadores de violão na varanda e canta, visivelmente emocionada, a música "Volver", da famosa cantora espanhola de flamenco Estrella Morente.

O diálogo musical intertextual entre Raimunda e Paula, ambas abusadas e ambas vingadoras do abuso, tornaram a minha viagem deliciosamente reconfortante no momento quando "vou ver" que a escrita é justamente o meu modo de reagir ao abuso e ao silenciamento social imposto sobre tal violência. "Como elemento de treino de si, a escrita tem, para utilizar uma expressão que se encontra em Plutarco, uma função "etopoiética": é um operador da transformação da verdade em ethos" (FOUCAULT, 2006, p.147). Mas o ethos que tento produzir aqui nessas linhas nem de longe reafirma, promove ou "diz-certa-ação", ao contrário, ela recorta, fatia, produz cortes na coerência e no modus operandi acadêmico: uma espécie de escrita da família dos falconídeos, carcaraniana. Se a cantora "pega, mata e come", aqui eu "Volver", fatio e escrevo!

O papel da escrita é construir, com tudo que a leitura constituiu, um 'corpo' (quicquid lectione collectum est, stilus redigat in corpus). E, este corpo, há que entendê-lo não como um corpo de doutrina, mas sim - de acordo com a metáfora tantas vezes evocada da digestão - como o próprio corpo daquele que, ao transcrever as suas leituras, se apossou delas e fêz (sic) sua a respectiva verdade: a escrita transforma a coisa vista ou ouvida 'em forças e em sangue' (in vires, in sanguinem). Ela transforma-se, no próprio escritor, num princípio de ação relacional (FOUCAULT, 2006, p.152). 
Não à toa a faca usada por Paula para dar fim ao seu abusador (Fig. 8) é a mesma faca utilizada no preparo do alimento (Fig. 9) da festa em que Raimunda, acompanhada por Ramon, por Paula, por Alicia, por Ignácio e por todas as corporalidades que foram abusadas, continua a cantar.

Figura 9 - Raimunda usa a mesma faca que matou o abusador para preparar o alimento - cena do filme Volver (2005)

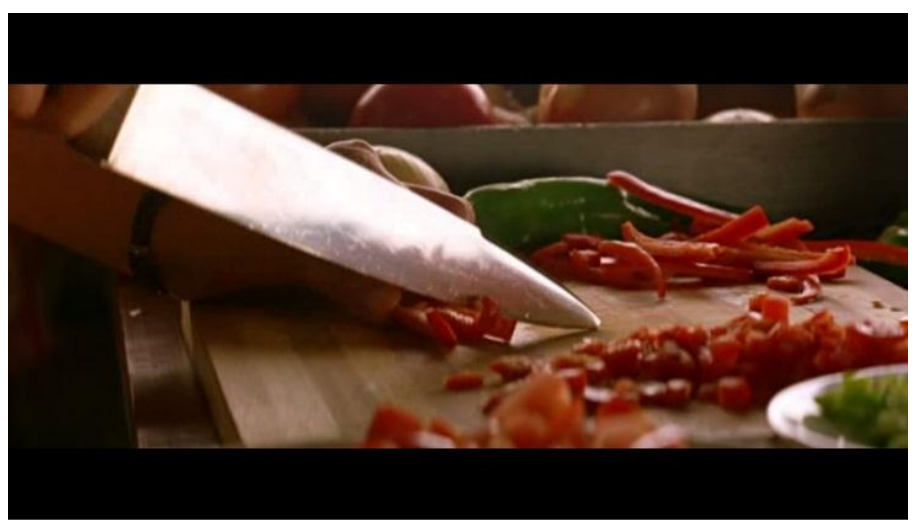

O viajante que antes fugia, hoje detém o seu fugir. Ao fatiar os temperos dissertativos o viajante-cozinheiro tenta produzir novos alimentos, novos pratos, novas formas de comer, novas formas de escrever com os ingredientes disponíveis. Numa espécie de mexidão ${ }^{15}$ gastronômico tento utilizar a minha corporalidade e minha subjetividade para fazer com que outrxs tantxs também reflitam sobre as violências cotidianamente produzidas e reproduzidas pela heteronorma. Se para Foucault o papel da escrita é produzir um corpo atento às normas de doutrinação, é inegável que, ao reescrever o abuso sexual sofrido pelo Ramon infante, estou me afinando com a prática cartográfica nos explicitada nos termos de Suely Rolnik (2014). Isto é, ao cartografar as paisagens das subjetividades infantis, pratico três ações: a ação de desejar, a ação de produzir vida[S] e a ação de fazer política. Vou ver

\footnotetext{
${ }^{15}$ Mexidão é uma receita típica de muitos lares brasileiros que nada mais é do que a utilização de vários ingredientes das sobras de pratos dos dias anteriores na confecção de um novo prato. É muito comum após as festas natalinas o mexidão feito com os ingredientes das sobras do peru, do arroz com passas etc. A internet está recheada de receitas de mexidão. Como bom baiano sugiro o "Mexidão Doido Baiano", receita disponível em: < http://goo.gl/gY4rU8>. Acesso em 12 set. 2016.
} 
uma produção violenta sobre os corpos infantis e suas subjetividades, utilizo minha dissertação-revólver para matar subjetiva e discursivamente os abusos, ao mesmo tempo em que trago à vida todas as vozes que foram silenciadas [pelo abuso e pela heteronorma]: façoas falar, faço-as denunciar seus abusadores, faço-as viajar em seus próprios rios. Por último, e aqui para mim é a atitude mais importante desse trabalho, luto, politicamente, para denunciar os discursos sociais que colocam a criança abusada em dois, e únicos papéis sociais possíveis, o do algoz [pelo qual devemos nutrir medo e vigilância] e o da vítima [pelo qual devemos nutrir piedade, cuidado e tratamento]. Luto, politicamente, para empreender um movimento de desregulação do abuso sexual, luto em prol do não-silenciamento.

Dessa forma, como expressei anteriormente, cartografo as paisagens psicossociais de uma infância violentada, buscando traçar itinerários possíveis para a ressignificação do adoecimento psíquico de tais subjetividades violentadas. Escrevo um relato de mim mesmo, mas escrevo, também, afetado por uma série de normatizações e interpelações que foram contemporâneas à criança que fui. Não significa apenas viajar à margem do rio e cantar alucinadamente, significa preocupar-se com os acordes, com o repertório, com os músicos que me acompanharão e com a platéia. A platéia, última instância desse espetáculo, é o componente principal dessa performance. Como diz/canta Maria Bethânia: "Sem ela não se anda. Ela é a menina dos olhos de Oxum, flecha que mira o sol. Oyá de mim!"16. Daí que inspirado por Judith Butler (2015) faço um relato de mim mesmo, performo a minha própria violência para uma platéia interessada [ou não], canto solo, em dueto, em coro, canto com outrxs corpos, canto com outras vozes. Ouço o canto da Iara $^{17}$, mas longe de encantar-me, convido-a para cantar junto.

\footnotetext{
${ }^{16}$ Na canção "A Dona do Raio e do Vento", faixa 4 do Ato 1 do DVD "Carta de Amor" (2013).

17 "A Iara é uma personagem do folclore brasileiro. Ela é uma linda sereia que vive no rio Amazonas, sua pele é morena, possui cabelos longos, negros e olhos castanhos. A Iara costuma tomar banho nos rios e cantar uma melodia irresistível, desta forma os homens que a veem não conseguem resistir aos seus desejos e pulam dentro do rio. Ela tem o poder de cegar quem a admira e levar para o fundo do rio qualquer homem com o qual ela desejar se casar." Disponível em: <http://brasilescola.uol.com.br/folclore/iara.htm>. Acesso em 12 set. 2016.
} 
Quando o 'eu' busca fazer um relato de si mesmo, pode começar consigo, mas descobrirá que esse 'si mesmo' já está implicado numa temporalidade social que excede suas próprias capacidades de narração; na verdade, quando o 'eu' busca fazer um relato de si mesmo sem deixar de incluir as condições de seu próprio surgimento, devo, por necessidade, tornar-se um teórico social. A razão disso é que o 'eu' não tem história própria que não seja também a história de uma relação - ou conjunto de relações - para com um conjunto de normas [corporalidades e subjetividades - grifo meu] (BUTLER, 2015, p.18).

Novamente, num dueto com Maria Bethânia, parodio a canção e, juntxs, reagimos contra os abusos sexuais, contra as normas silenciadoras de nossos corpos e subjetividades dissidentes:

Quando choro, se choro, é pra regar o capim que alimenta a vida, [escrevendo] eu e faço as nascentes que você secou.

Não mexe comigo, eu não ando só.

Música "Carta de Amor", presente no DVD "Carta de Amor" (2013).

"Escrever é, pois, 'mostrar-se', dar-se a ver, fazer aparecer o rosto próprio junto ao outro" (FOUCAULT, 2006, p.156). Quando escrevo uma espécie de justiça é cumprida, tenho a nítida sensação de conseguir falar, uma liberdade ansiada há muito, mas que pela incidência dos poderes heteronormativos, foi adiada até quase acreditar que não existiria mais possibilidades de reação. Ao final de tudo revelo, axs caríssimxs leitorxs que me acompanharam durante essa viagem, que é possível sim empreender um outro tipo de ação que não seja produtora e reprodutora de violências, contra as subjetividades e corporalidades que são cotidianamente subalternizadas ou, como sintetiza Butler (2015):

Não há criação de si (poiesis) fora de um modo de subjetivação (assujettisement) e, portanto, não há criação de si fora das normas que orquestram as formas possíveis que o sujeito deve assumir. A prática da crítica, então, expõe os limites do esquema histórico das coisas, o horizonte epistemológico e ontológico dentro do qual os sujeitos podem surgir. Criar-se de tal modo a expor esses limites é precisamente se envolver numa estética de si- 
mesmo que mantém uma relação crítica com as normas existentes (BUTLER, 2015, p.29).

\title{
Considerações finais
}

\begin{abstract}
Uma operação crítica não pode acontecer sem essa dimensão reflexiva. Pôr em questão um regime de verdade, quando é o regime que governa a subjetivação, é pôr em questão a verdade de mim mesma e, com efeito, minha capacidade de dizer a verdade sobre mim mesma, de fazer um relato de mim mesma. Desse modo, se questiono o regime de verdade, questiono também o regime pelo qual se atribuem o ser e minha própria condição ontológica (BUTLER, 2015, p.35).
\end{abstract}

Por todas essas linhas eu volto a perguntar: quem pode falar dentro desses cenários de abuso e violência? Se xs nobres leitorxs já estiverem cansadxs certamente a resposta [única] recai sobre as personagens da família nuclear burguesa, sobre as disciplinas médico-patologizantes, sobre as teorias subjetivas que mitologizam e aprisionam o inconsciente, sobre a academia promotora de uma produtividade fordista e desprovida de emotividade, todas elas produzem e reproduzem a heteronorma sob qual os nossos corpos, nossos gêneros, nossas sexualidades e nossas violências são todas naturalizáveis e nunca passíveis de bem-estar, luto e reconhecimento.

Por outro lado, se vocês, leitorxs de meus rios, assumirem de antemão que "as normas pelas quais eu reconheço o outro ou a mim mesma não são só minhas", certamente "o horizonte normativo no qual eu vejo o outro e, com efeito, no qual o outro me vê, me escuta, me conhece e me reconhece também é alvo de uma abertura crítica" (BUTLER, 2015, p.37). Nesse sentido, a multiplicidade e a diferença potencializam as vozes, o volume das multidões queer (PRECIADO, 2011) é aumentado e o medidor de decibéis pifa, pois não conseguem catalogá-lo e encaixálo em escalas. Então a resposta para a pergunta "quem pode falar dentro desses cenários de abuso e violência?" é infinita. Falam Ramons, Pinas, Alicias, Raimundas, Ignácios, Paulas, Penélopes, Pedros, Marias. Falam encantados, santos, orixás, ventos, rios, mares... Falam os abusos, falam os silêncios, falam os infantes. Falam as facas, falam os livros, falam as bebidas alcoólicas, falam a maconha, falam a cocaína, falam o coquetel. 
Falamos, violentados, em múltiplas línguas, em múltiplos filmes, em múltiplos encontros. No final de tudo continuamos a "Falar com ela".

\section{Referências}

A DONA do Raio e do Vento", cantada por Maria Bethânia, faixa 4 do DVD "Carta de Amor", 2013.

ANDRADE, Carlos Drummond de. Alguma poesia. Belo Horizonte: Edições Pindorama, 1930.

ARIÈS, Philippe. História social da infância e da família. Tradução: D. Flaksman. Rio de Janeiro: LCT, 2014.

ÁTA-ME (¡Átame!). Escrita e Direção: Pedro Almodóvar. Produção: Augustín Almodóvar. Intérpretes: Victoria Abril, Antonio Banderas, Loles León, Julieta Serrano, Rossy de Palma, Franscisco Rabal. Música: Ennio Morricone. Espanha: El Deseo, 1990. 1 DVD (101MIN), LETTERBOX, COLOR. Produzido por El Deseo.

BUTLER, Judith. Relatar a si mesmo: crítica da violência ética. (1 ed.). (Rogério Bettoni, Trad.) Belo Horizonte: Autêntica Editora, 2015.

. Problemas de gênero - Feminismo e subversão da identidade (3 ed.). (R. Aguiar, Trad.) Rio de Janeiro: Civilização Brasileira, 2010.

FALE COM ELA (Hable com ella). Escrita e Direção: Pedro Almodóvar. Produção: Augustín Almodóvar. Intérpretes: Javier Cámara, Dario Grandinetti, Rosario Flores, Leonor Watling, Caetano Veloso e outros. Música: Alberto Iglesias. Espanha: El Deseo, 2002. 1 DVD (112MIN), LETTERBOX, COLOR. Produzido por El Deseo.

FOUCAULT, Michel. A escrita de si (p. 144-162). In: Ditos e Escritos V - Michel Foucault: Ética, sexualidade, política; Organização e seleção de textos Manoel Barros da Motta; tradução Elisa Monteiro, Inês Autran Dourado Barbosa. - Rio de Janeiro: Forense Universitária, 2006.

Os anormais: curso no Collège de France (1974-1975). Tradução: Eduardo Brandão - $2^{\mathrm{a}}$ Ed. São Paulo: Editora WMF Martins Fontes, 2010. 
História da sexualidade 1 - A vontade de saber. (M. T. Albuquerque, \& J. A. Albuquerque, Trads.) Rio de Janeiro: Edições Graal, 1988.

História da sexualidade 3 - O cuidado de si. (Maria Thereza da Costa Albuquerque, \& José Augusto Guilhon Albuquerque, Trads.) Rio de Janeiro: Edições Graal, 1985.

GRANATO, ALICE. "Pedro Almodóvar: Vida que não cabe em filme - O maravilhoso mundo do diretor mais fervido da Espanha", São Paulo, Serafina, p. 46-53, Setembro, 2009.

HOHENDORFF, Jean Von; HABIGZANG, Luísa Fernanda; KOLLER, Silvia Helena). Violência sexual contra meninos: dados epidemiológicos, características e consequências. Psicol. USP, São Paulo, v.23, n.2, p. 395-416, 2012. Disponível em <http://goo.gl/8phSHl> Acesso em 22 ago. 2016.

Iara - A lenda. Disponível em: $<$ http://brasilescola.uol.com.br/folclore/iara.htm>. Acesso em 12 set. 2016

JESUS, J. G. Identidade de gênero e políticas de afirmação identitária. In: ABEH. Congresso Internacional de Estudos sobre a Diversidade Sexual e de Gênero. Salvador, 2012.

LOURO, Guacira Lopes. Um corpo estranho: ensaios sobre sexualidade $e$ a teoria Queer. Belo Horizonte: Autêntica, 2004.

MÁ EDUCAÇÃO (La mala educación). Escrita e Direção: Pedro Almodóvar. Produção: Augustín Almodóvar. Intérpretes: Gael García Bernal; Fele Martínez; Daniel Giménez Cacho; Lluis Homar; Francisco Boira; Javier Cámara e outros. Editor: José Salcedo. Música: Alberto Iglesias. Espanha: El Deseo, 2003. 1 DVD (105MIN), LETTERBOX, COLOR. Produzido por EI Deseo.

MINISTÉRIO DA JUSTIÇA E CIDADANIA DO GOVERNO FEDERAL DO BRASIL (Secretaria Especial de Direitos Humanos). Campanha - Respeitar, proteger, garantir: Prevenção e enfrentamento à violência sexual. Disponível em: < http://goo.gl/hfVsQO>. Acesso em 22 ago. 2016

MINISTÉRIO DA SAÚDE DO GOVERNO FEDERAL DO BRASIL. Sistema de Vigilância de Violências e Acidentes (Viva) : 2009, 2010 e 2011. Disponível em <http://goo.gl/zxaryc> Acesso em: 22 de ago. 2016. (2013) 
PRECIADO, Beatriz (Paul B. Preciado). Quem defende a criança queer? Cícero Oliveira (trad.). Revista Virtual Geni, n.16, out. 2014. Disponível em < http://revistageni.org/10/quem-defende-a-criancaqueer/>. Acesso em: 13 jun. 2016.

PRECIADO, Beatriz (Paul B. Preciado). Multidões queer: notas para uma política dos "anormais". Cleiton Zóia Münchow e Viviane Teixeira Silveira (trad.). Revista Estudos Feministas, v.19, n.1, 2011. Disponível em <https://periodicos.ufsc.br/index.php/ref/article/view/S0104026X2011000100002/18390>. Acesso em: 09 set. 2016.

"RESISTIRÉ" , cantada pela banda Duo Dinâmico, 1988.

ROLNIK, Suely. Cartografia sentimental: transformações contemporâneas do desejo. Porto Alegre: Sulina; Editora UFRGS, São Paulo, 2014.

STRAUSS, Frederic. Conversas com Almodóvar. Rio de Janeiro: Zahar, 2008.

UNICEF. Ocultos a plena luz. Un análisis estadístico de la violencia contra los niño. 2014. Disponível em <http://goo.gl/0cG3ig > Acesso em: 22 ago. 2016.

VOLVER. Escrita e Direção: Pedro Almodóvar. Produção: Esther García. Intérpretes: Penélope Cruz; Carmen Maura; Lola Dueñas; Blanca Portillo; Yohanna Cobo e Chus Lampreave. Montagem: José Salcedo. Música: Alberto Iglesias. Profutor Executivo: Augustín Almodóvar. Espanha: El Deseo, 2005. 1 DVD (121MIN), WIDESCREEN ANAMÓRFICO, COLOR. Produzido por EI Deseo. 